\title{
MODEL PENGEMBANGAN PERMAINAN PERESEAN DALAM MENINGKATKAN MINAT OLAHRAGA TRADISIONAL PADA SISWA KELAS X DI SMA NEGERI 1 PRAYA TIMUR
}

\author{
Suryansah $^{1)}$, Karno Dinata ${ }^{2)}$, Didik Daniyantara ${ }^{3)}$ \\ Prodi Pendidikan Jasmani Kesehtan dan Rekreasi Fakultas Ilmu Pendidikan \\ Universitas Hamzanwadi \\ email: ${ }^{1}$ suryansahtkd@yahoo.com \\ ${ }^{2}$ karnodinata111@gmail.com \\ 3daniyantara_didik@yahoo.com
}

\begin{abstract}
ABSTRAK
Penelitian ini bertujuan untuk mengembangkan produk alat peresean dari yang ekstrim atau berbahaya menuju tidak berbahaya sehingga diminati dari kalangan usia 16 tahun keatas yaitu siswa kelas X SMA Negeri 1 Praya Timur. Metode penelitian kuantitatip, Prosedur model pengembangan produk diantaranya analisis kebutuhan, merencanakan bentuk produk, uji coba produk, perbaikan produk, uji lapangan, revisi hasil akhir produk. Populasi penelitian siswa kelas $\mathrm{X}$ sedangkan sampel penelitian ditentukan melalui pengukuran sampel dengan sistematic random sampling, sebanyak 40 siswa, jenis data penelitian deskriftip kuantitatif. Instrumen penelitian dengan lembar observasi, lembar kuesioner dan lembar wawancara. Pengumpulan data dan analisis data dengan teknik deskriptif bersifat persentase. Hasil penelitian ialah responden yang diujikan pada kelompok kecil diperoleh sebagian besar menjawab "Ya" dengan nilai 75\%. Kemudian hasil uji lapangan terjadi peningkatan yaitu responden menjawab "Ya" dengan nilai 85\%.
\end{abstract}

Kata Kunci: model pengembangan, permainan peresean, minat

\section{ABSTRACT}

The research aims to preserve traditional peresean sports at the upper school level with the development model of peresean game tools so as to increase the interest of class $X$ students of East Praya 1 High School. Descriptive research methods, product development model procedures include needs analysis, product form planning, product testing, product improvement, field testing, product final revision. The research population of class $X$ students while the research sample was determined by measuring samples with sistematic random sampling, as many as 40 students, types of quantitative and qualitative research data, research instruments with observation sheets, questionnaire sheets and interview sheets, data collection and data analysis with descriptive techniques in the form of percentages and responses based on interviews. The results of the study were that the respondents who were tested in small groups were obtained, most of them answered yes with an average value of $75 \%$. While the results of field tests most respondents answered yes with an average value of $85 \%$.

Keywords: development of Model, games traditional peresean, interest

$\bowtie$ Alamat korespondensi:

E-mail: suryansahtkd@yahoo.com

C 2019 IKIP BUDI UTOMO MALANG

Info Artikel

Dikirim : 9 Agustus 2019

Diterima : :21 Oktober 2019

DOI $\quad:$ https://doi.org/10.33503/jp.jok.v3i1.519 


\section{PENDAHULUAN}

Nusa Tengara Barat (NTB) memiliki beragam budaya dan ciri khas yang tercermin serta dieksperisikan dalam olahraga tradisional. Olahraga tradisional merupakan suatu permaianan rakyat yang dicetuskan oleh orang tua terdahulu yang tumbuh dan berkembang secara turun temurun serta memiliki keunikan dan daya tarik tersendiri. Olahraga tradisional dapat memberikan manfaat bagi tubuh yaitu meningkatkan kesehatan, kebugaran jasmani dan menambah keterampilan gerak. Keterampilan gerak bertujuan untuk menjaga keselamatan diri sendiri serta mencapai waktu luang dengan aktivitas yang bersifat rekreatif (Taufan, Ardisal, Damri, \& Arise, 2018). Olahraga tradisional terdiri dari permainan balemparan, jalan dengan babu (enjang-enjag), bentangan, selodoran, gangsingan dan peresean. Presean adalah adat istiadat suku sasak Lombok yang bersenjatakan rotan (penyalin), menggunakan tameng (ende) yang terbuat dari kulit sapi dan saat acara presean berlangsung akan di iringi dengan gendang (gending). Olahraga peresean adalah suatu olahraga yang dimainkan oleh dua orang yang saling berlawanan dengan menggunakan tameng atau ende dan disertai rotan sebagai alat pemukul (Rajab \& Kuswantoro, 2018). Permainan peresean bermanfaat bagi fisik selain meeningkatan kebugaran jasmani juga meningkatan keterampilan dan mental emosional serta social (Husnan, 2009).

Dalam cabang olahraga terdapat 10 aspek kondisi fisik, sedangkan permaianan peresean dapat meningkatkan daya tahan, daya ledak otot lengan, fleksibelitas lengan dan badan, reaksi, mental, dan kelincahan. Olahraga permainan peresean dipertandingkan pada saat tertentu seperti peringatan hari ulang tahun disetiap Kabupaten salah satunya Kabupaten Lombok Tengah. Permainan peresean dimainkan oleh masyarakat umum dikalangan dewasa maupun remaja. Remaja ialah usia Sekolah Menengah Atas (SMA), siswa SMA Negeri dan sederajat pada dasarnya menyenagi permainan peresean, tetapi terkesan membahayakan dan ekstrim sehingga banyak diantara siswa tidak berani untuk melakukan. Hal ini berdampak pada minta siswa berangsur pudar bahkan punah. Minat adalah keinginan yang dimunculkan karena adanya ketertarikan pada diri seseorang untuk dapat dijadikan sebagai pendorong dalam melakukan kegiatan sesuai dengan tujuan. (Rahayu \& Firmansyah, 2019). Minat muncul dari 
panca indra seseorang kemudian diperkuat oleh sikap positif dan negatif, artinya bila minat positif dalam beraktivitas, maka semakin besar peluang untuk mencapai keberhasilan, dan bila minat seseorang negatif dalam beraktivitas, maka peluang mencapai keberhasilan kecil. Sebagaimana yang diungkapkan oleh (Djaali, 2011). Minat merupakan penerimaan terhadap sesuatu yang ada hubungannya antara diri sendiri dengan sesuatu di luar diri yang dpat berpengaruh dalam mencapai prestasi disuatu bidang pekerjaan, jabatan, atau karir.

Selama ini permainan peresean di Lombok Tengah tingkat SMA Negeri, sederajat direspon kurang baik oleh warga sekolah. SMA Negeri 1 Praya Timur merupakan salah satu Sekolah yang ada di Lombok Tengah dan satu-satunya di Kecamatan Praya Timur dengan kapasistas 1000 siswa/siswi. Pembelajaran pendidikan jasmani kesehatan (Penjaskes) di sekolah sampai saat ini selalu berorientasi pada pengajaran cabang olahraga moderen yang sifatnya mengarah pada penguasaan skill untuk dipertandingkatn tingkat Lokal, Regional, Nasional. Warga SMA Negeri 1 Praya Timur memiliki latar belakang budaya lokal, salah satunya permainan peresean.

Permainan peresean tidak diprogramkan bahkan diekstrakulikuler. Hal ini berdampak pada pudarnya respon dan minat siswa. Menggapi fenomena tersebut memerlukan model yang berbeda dari bentuk peralatan peresean yang sudah ada, agar tidak terkesan membahayakan. Faktor yang mempengaruhi minat yaitu fatkor internal dan eksternal. Aspek eksternal seperti dukungan guru, kurikulum dan latar belakang budaya, (Sriyatin, Sucipto, \& Sulikan, 2018). Hal ini dapat diperkuat dengan wawancara peneliti bersama guru penjaskes menyatakan selama ini permainan peresean tidak pernah dilakukan dan tidak diekstrakulikuler, karena diprogramkan di kurikulum maupun sekolah, permainan peresean membahayakan yang menjadikan siswa kurang tertarik. Dari hasil penelitian yang dilakukan oleh (Rosianah, R, \& Setiawan, 2012)menyimpulkan bahwa permainan tradisional gobag sodor bola dapat digunakan guru penjas sebagai permainan alternatif dalam pembelajaran penjaskes. (Firmansyah \& Rahayu, 2019) permainan tradisional engklek yang dimodifikasi dapat meningkatkan gerak motorik kasar pada anak. Berdasarkan penjelasan di atas permainan peresean tidak mendapatkan respon positif dari sekolah, sehingga 
peneliti tertarik untuk mengkaji model pengembangan permainan peresean dalam meningkatkan minat olahraga tradisional pada siswa. Peneliti berharap dengan model pengembangan alat permainan peresean dapat meningkatkan minat olahraga tradisional pada siswa agar dapat diaplikasikan dan dikembangkan.

\section{METODE}

Metode penelitian yang digunakan yaitu penelitian dan pengembangan $(R$ and $D)$ merujuk pada metode penelitian yang digunakan (Suharnoko \& Firmansyah, 2018). Penelitian pengembangan adalah suatu proses yang digunakan untuk mengembangkan dana tau mengabsahkan produk yang digunakan dalam pendidikan pembelajaran (Setyosari \& Punaji, 2010). Produk yang ingin dihasilkan ialah produk alat peresean, dengan tujuan mengembangkan produk dan menguji keefektifan produk sesuai dengan tujuan yang ingin dicapai.

1. Prosedur Model Pengembangan

Prosedur pengembangan ialah suatu proses yang digunakan dalam pendidikan dan pengajaran dalam menguji keefektifan produk untuk mencapai tujuan, (Setyosari \& Punaji, 2010). Adapun model Pengembangan permainan peresean, dilakukan melalui beberapa tahap, antara lain:

1) Analisis Kebutuhan, ialah tahap awal dalam melakukan penelitian untuk menentukan apakah model alat peresean dapat diterapkan sebagai pembentukan minat dalam mentradisikan olahraga tradisional di SMA Negeri 1 Praya Timur. Peneliti melakukan observasi dan mengumpulkan informasi melalui penyebaran kuesioner ke setiap responden, untuk menjawab tingkat kegemaran permainan peresean.

2) Merencanakan bentuk produk awal, Berdasarkan analisis kebutuhan tersebut, dan mengacu pada teori-teori yang ada, kemudian peneliti merancang produk alat peresean untuk diskusikan dengan dua ahli peresean dan guru penjas setelah itu akan dibuat untuk diuji coba pada beberapa siswa.

3) Uji coba produk, Pelaksanaan uji coba produk dilakukan dengan Menetapkan rancangan uji coba, Menentukan subyek uji coba, Menyusun instrumen pengumpulan data dan Menetapkan analisis data. 
4) Perbaikan produk yang diuji coba, Setelah dilakukan uji coba produk bersama-sama dengan para ahli dan guru penjas untuk dikaji dimana letak ke kurangan produk tersebut untuk lakukan perbaikan.

5) Uji lapangan, akan dijadikan sebagai tahap akhir dari perbaikan produk yang dilakukan pada subjek penelitian pada siswa kelas X SMA Negeri 1 Praya Timur sebanyak 40 siswa. dari uji coba responden akan diberi penjelasan tentang teknik dan peraturan permainan peresean.

6) Revisi produk akhir yang dilakukan berdasarkan hasil uji lapangan.

Hasil akhir produk ini akan dijadikan sebagai produk pengembangan sarana dan prasarana permainan peresean pada siswa SMAN 1 Praya Timur dan sederajat.

Populasi adalah keseluruhan penduduk atau kelompok yang dimaksudkan untuk diselidiki paling sedikit mempunyai satu sifat yang sama (Riyanto, 2007). Populasi dalam penelitian ini adalah seluruh siswa Putra kelas X SMAN 1 Praya Timur yang berjumlah 150 siswa/siswi. Sampel adalah sebagian atau wakil dari populasi yang diteliti(Riyanto, 2007). Pengambilan sampel menggunakan teknik random sampling. Sampel dalam penelitian ini adalah siswa putra kelas X pada SMAN 1 Praya Timur yang berjumlah 40 Siswa.

\section{Rancangan Penelitian}

Rancangan produk yang berupa peralatan permainan peresean yang sudah ada untuk dikembangkan agar bervariasi sehingga terkesan tidak membahayakan dan ekstrim. Adapun rancangan yang dilakukan sebagai berikut:

1) Pravalidasi artinya peneliti melakukan Sharing dengan guru penjas SMAN 1 Praya timur dan dua ahli persean, tujuan agar dapat saran dan masukan untuk ditetapkan.

2) Validasi artinya peneliti bersama ahli dan guru penjas melakukan perbaikan terhadap peralatan peresean yang belum optimal. Unsur kelayakan optimal terdiri dari perisai (ende), rotan (penyalin) sebagai alat pukul, bola plastik dan gabus yang ditutup pakai sapuk, pengaman siku lengan.

3) Uji coba responden artinya Produk yang sudah divalidkan akan ditetapkan sebagai alat permainan peresean untuk digunakan oleh siswa SMAN 1 Praya Timur. 
3. Instrumen Penelitian

Instrumen Yang digunakan dalam penelitian ini ialah

1) Lembar kuesioner bersifat favorable dan unfavorable.

2) Lembar wawancara pada guru dan ahli

3) lembar observasi praktek permainan peresean

4. Pengumpulan Data

Teknik pengumpulan data, akan dijadikan satu berdasarkan hasil dari jawaban resonden. Untuk mengetahui rentang jawaban, peneliti mengunakan pilihan jawaban Ya dan Tidak. Bila jawaban ya skor 1, dan jawaban Tidak skor 0 . Selanjutnya skor jawaban dijumlah untuk mengetahui besarnya minat siswa dalam mengaplikasikan dan menerapkan permainan peresean. Sedangkan untuk ahli dan guru penjas mengunakan panduan wawancara serta panduan observasi praktek permainan peresean.

5. Analisis Data Penelitian

Penelitian model pengembangan permainan peresean menggunakan teknik analisis data deskriptif kuantitatif berbentuk presentase, dan data yang bersipat tangapan akan menggunakan teknik analisis kualitatif.

\section{HASIL DAN PEMBAHASAN}

Model permainan peresean yang dikembangkan dalam penelitian ini adalah bentuk alat permainan peresean dengan tujuan agar menarik serta meningkatan minat siswa pada olahraga tradisional. Proses penelitian ini mengacu kepada prosedur analisis kebutuhan sebagai bahan pertimbangan dimasa yang akan datang, karena alat permainan peresean masa lalu sampai masa kini masih berkesan ekstrim. Oleh karena itu penelitian pengembangan alat permainan peresean ini diawali dengan tahap studi pendahuluan atau analisis kebutuhan, tahap ini dilakukan agar mendapatkan informasi yang akurat melalui pertanyanpertanyaan berbentuk kuesioner, kemudian merancang bentuk produk awal, uji coba produk, perbaikan produk, uji lapangan dan revisi produk akhir yang dilakukan berdasarkan hasil uji lapangan.

a) Analisis kebutuhan dilakukan sebagai langkah awal dalam melaksanakan penelitian untuk memperoleh model pengembangan permainan peresean dalam meningkatkan minat olahraga tradisional. Dari hasil observasi diperoleh, belum 
ada sarana dan prasarana permainan peresean serta belum diprogramkan oleh sekolah sehingga saat ekstarkuriker pun belum dilaksanakan. Sejalan dengan observasi tersebut peneliti juga melakukan uji coba ke siswa sebagai responden, dengan cara menyebarkan kuesioner.

Berdasarkan jawaban responden dari uji coba kuesioner diperoleh berbanding terbalik, artinya lebih sedikit siswa menjawab Ya dari pada Tidak. Siswa dengan jawaban "Ya" dengan nilai persentase tertinggi sebesar (42.9\%), (40.7\%) dan (39.2\%). Sedangkan siswa dengan jawaaban "Tidak" dengan nilai persentase dari (42.9\%), (39.6\%) dan (38.3\%). Dari jawaban siswa yang sudah diadopsi dalam bentuk persentase tersebut maka dapat diartikan bahwa sebagian besar responden berminat untuk mengunakan model pengembangan prasarana permainan peresean.

b) Merancang model produk awal

Dari hasil jawaban tersebut diatas selanjutnya peneliti akan merancang model produk awal dengan tahapan-tahan sebagai berikut yaitu:

(1) Pra-validasi

Pravalidasi merupakan tahap awal dalam pembentukan produk yang sudah ada untuk dikembangkan melalui penambahan sarana sehingga menjadi produk terbaru yang dapat menarik minat responden. Persamaan persepsi menjadi landasan utama dalam perancangan produk, dalam hal ini peneliti mengundang dua ahli peresean dan guru penjaskes, agar memperoleh masukan untuk ditetapkan sebagai tahap pelaksanaan peneitian.

(2) Validasi

Setelah dikomunikasikan dan didiskusikan kemudian dapat menyepakati kesimpulaan maka selanjutnya peneliti menampilkan produk peresean, Adapun produk rancang tersebut, sebagaimana tertera pada gambar-gambar di bawah ini:
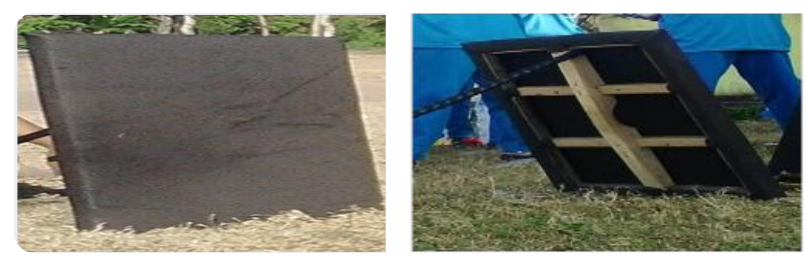

Gambar 1. Tameng atau Ende Tampak Luar dan Dalam yang sudah di modifikasi 


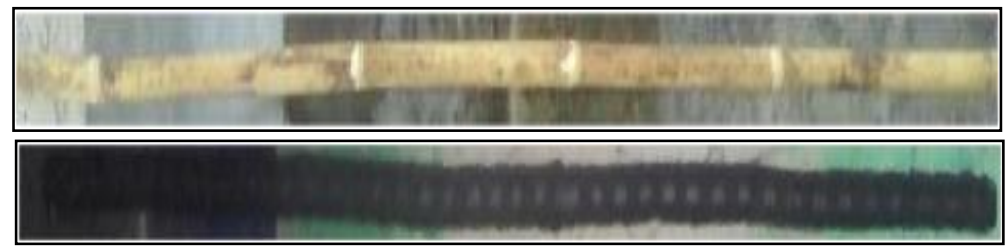

Gambar 2. Alat Pemukul atau Penyalin (Rotan) yang sudah di modifikasi
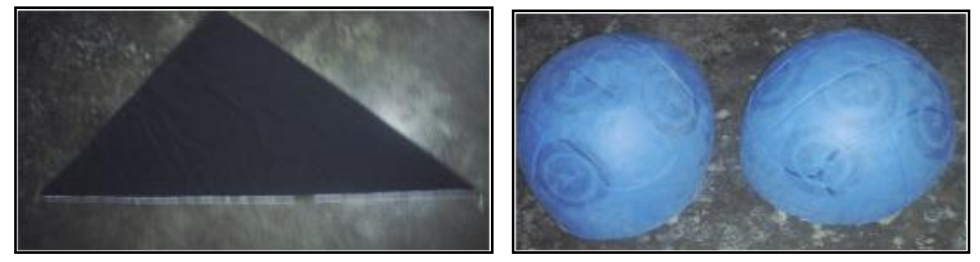

Gambar 3. Sapuk (ikat kepala) dan Pelindung Kepala yang sudah dimodifikasi

c) Uji coba produk

Produk di ujikan kepada kelompok kecil yang terdiri dari 6 (enam) responden tentunya dengan menggunakan produk yang sudah dirancang sebagaimana yang terlihat pada gambar di atas. Berikut ini adalah hasil uji coba:

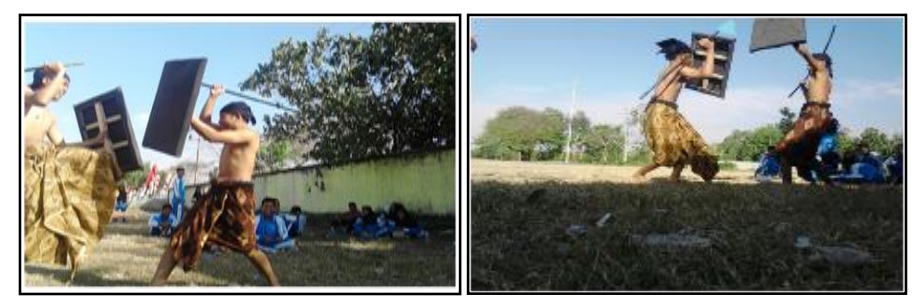

Gambar 4. Pertanding Peresean

Dari hasil uji coba produk pada kelompok kecil diatas maka diperoleh responden tidak khawatir meski kena karna tidak membuat luka, hal ini di peroleh dari pengakuan responden saat penyebaran kuesioner. diujikan pada kelompok kecil diperoleh nilai persentasi rata 75\%. Artinya model pengembangan permainan peresean dalam meningkatkan minat olahraga tradisional pada siswa kelas X SMAN 1 Praya Timur, dapat digunakan untuk uji coba lapangan.

d) Perbaikan produk yang diuji coba

Berdasarkan data yang diperoleh dari siswa, model pengembangan permainan peresean maka para ahli mendapatkan beberapa hal yang perlu untuk diperbaiki atau ditambah. Menurut ahli peresean yang harus ditambah pada alat peresean itu adalah penyalin (alat pemukul) dengan ditambah busanya agar tidak 
terlalu sakit saat kena penyalin tersebut. Guru penjaskes menyarankan agar siswa diberikan latihan terlebih dahulu baik tata cara memukul maupun teknik menangkis serta diberikan latihan motorik.

\section{e) Uji Lapangan}

Uji lapangan merupakan uji terakhir pada responden untuk mengabsahkan produk yang sudah direvisi oleh para ahli. Uji lapangan ini berlaku untuk semua responden, akan tetapi diwakili oleh sebagian responden dengan melihat minat responden yang masih kurang atau kurang respon dan responen yang semangat. Berikut adalah gambar responden saat melakukan peresen dengan model yang sudah direvisi, adalah sebagai berikut:
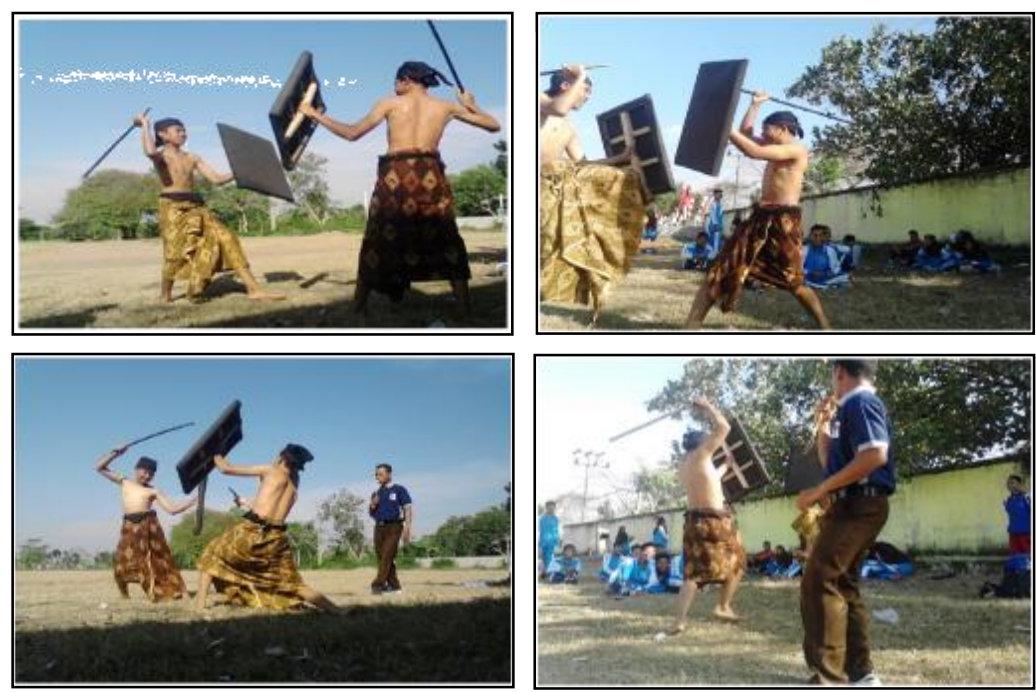

Gambar 7. Pertandingan Peresean

Berdasarkan hasil uji lapangan pada responden kelompok besar maka diperoleh bahwa responden antusias memainkan produk peresean, tidak ragu dan saling pukul memukul karena merasa penyalin tidak membuat sakit dan atau tidak berbekas sampai mengeluarkan darah. Para Pepadu mengunakan pakaian dari atas sampai bawah. pada bagian atas hanya menggunakan sapuk dan dilapisi busa untuk dililitkan di kepala, kemudian pada bagian badan sampai pinggang tidak mengunakan baju, selanjutnya pada bagian pinggang kebawah menggunakan celana didalamnya dan kain penutup celana atau tamper diluar, dan tamper tersebut dililit degan kain yang disebut bebet pinggang. (Husnan, 2009). 
Kemudian hasil uji produk pada kelompok besar tersebut di perkuat melalui penyebaran kuesioner pada responden, jawaban responden Sebagian besar "senang" dengan nilai rata-rata persentasi 85\%. Dengan demikian dapat disimpulkan bahwa model pengembangan permainan peresean dalam meningkatkan minat olahraga tradisional pada siswa kelas X SMAN 1 Praya Timur, sudah layak untuk diterapkan.Berkaitan dengan hasil diatas maka dapat di perkuat oleh pendapat dari ahli pembelajaran yakni guru penjaskes dan ahli peresean.

f) Revisi produk akhir yang dilakukan berdasarkan hasil uji lapangan.

Berdasarkan hasil uji lapangan yang diperagakan oleh siswa, maka para ahli mendapatkan beberapa hal yang perlu untuk diperbaiki atau ditambah. Menurut ahli pembelajaran guru penjaskes menyarankan agar siswa diberikan pemanasan terlebih dahulu agar mendapatkan perenggangan atau rileksasi otot. Sedangkan ahli peresean memberikan saran agar dikontrol oleh guru penjaskes saat praktek permainan peresean sehinngga dapat berjalan dengan lancar disampinng itu membuat alat pemukul atau penyalin yang sudah dimodifikasi dengan produk awal kemdian akan lebih semarak lagi bila ada musik atau gamelan.

\section{PEMBAHASAN}

\section{1) Analisis kebutuhan}

Berdasarkan hasil penelitian analisis kebutuhan maka model pengembangan permainan peresean dalam meningkatkan minat olahraga tradisional pada siswa kelas X SMA Negeri 1 Praya Timur adalah lebih 35\% siswa menjawab Ya, sebagaimana hasil dari kuesioner yang disebarkan kemasing-masing responden diambil dari nilai persentase terbesar ialah terdapat pada pertanyaan, Apakah olahraga tradisional membutuhkan alat pelindung kepala agar tidak bocor, Menurut anda olahraga tradisional membutuhkan alat perlindungan badan agar tidak terluka dan Menurut anda olahraga tradisional persean dapat menambah teman atau sahabat.Sedangkan $65 \%$ responden dengan jawaban Tidak, terdapat pada pertanyaan Apakah olahraga tradisional perseean sudah ada prasarana seperti ende dan penyalin di sekolah, Menurut anda olahraga tradisional dapat 
menjadikan kebutuhan dalam meniti karir atau prestasi pada olahraga dan Menurut anda olahraga tradisional peresean pernah diperagakan di sekolah. Dari jawaban tersebut diperkuat oleh pendapat ahli yaitu minat muncul karena ketertarik sehingga merasa senang, terpikat hatinya karena perasaan yang diperkuat oleh sikap yang positif, perhatian yang ada pada diri individu maupun dari luar individu. dan Kebutuhan adalah keadaan atau sifat pribadi yang menyebabkan meningkatnya attention atau perhatian. (Djaali, 2011).

\section{2) Desain model produk awal}

Setelah mengetahui minat responden masih rendah terhadap permainan peresean maka perlu untuk menyusun rancangan model produk, sebagaimana yang diperoleh maka mengundang beberapa ahli baik dari ahli peresean maupun guru penjas, tenntunya penneliti menjelaskan lebih awal planing yang nantinya dapat di tanggapi dan diberikan masukan-masukan sehingga produk tersebut dapat di uji cobakan kepada responden kelompok kecil. Sebagaimana yang diungkapkan oleh(Malik, Priyono, \& Qoriah, 2013)menyatakan perencanaan program perlu diperhatikan bagaimana mengidentifikasi kemampuan peserta didik berdasarkan kebutuhannya, mengklasifikasikan kelompok yang dapat dilaksanakan proses pembelajaran secara klasikal, mempersiapkan program berdasarkan tingkat kemampuan individu atau kelompok, melaksanakan pembelajaran berdasarkan program yang telah disusun dan melaksanakan evaluasi terhadap perkembangan atau kemajuan belajar serta meningkatkan keberhasilan dalam berpartisipasi dan melakukan pola gerak secara benar.

\section{3) Uji coba produk}

Sebagaimana yang telah dihasilkan dari pertemuan dengan para ahli dan memperoleh produk maka perlu untuk di uji coba pada kelompok kecil, selain produk di uji cobakan juga menggali lagi informasi dengan menanyakan kepada responden melalui pertanyaan-pertanyaan yang sudah disusun diperoleh $75 \%$ responden menjawab Ya, menurut anda olahraga tradisional peresean dapat dijadikan sebagai meluangkan rasa jenuh, Menurut anda olahraga tradisional dapat meningktakan ketangkasan dalam bergerak, Apakah olahraga tradisional 
peresean dapat membantu kelincahan. Menurut anda olahraga tradisional persean dapat menambah teman atau sahabat dan Apakah olahraga tradisional membutuhkan alat pelindung kepala agar tidak bocor. Hal ini juga dapat diperkuat oleh pendapat para ahli baik dari guru penjaskes dan ahli peresean yakni "Apabila mengacu pada kurikulum yang sudah ada pak, memang tidak ada tercantum tentang pembinaan olahraga tradisional peresean, namun dari kegemaran siswa Pengembangan model produk peresean boleh diterapkan" (AR Penjas, 48 th). Pemahaman tentang perminan peresean ini dengan Produk yang dikembangkan sangat perlu agar tradisi buaya sasak tidak hilang dan itu akan menyenaagkan bagi siswa khususnya yang laki-laki” (KP Ahli Peresean, 51 th).

Seseorang dikatakan berminat terhadap sesuatu bila dalam diri seseroang itu memiliki unsur: (a). Perhatian yaitu kreatifitas jiwa tinggi yang semata-mata tertuju pada suatu obyek. (b). Kesenangan artinyan Perasaan senang terhadap sesuatu obyek baik terhadap seseorang, benda maupun permainan yang menimbulkan minat pada dirinya. (c). Kemauan ialah dorongan yang terarah pada suatu tujuan dikehendaki oleh akal pikiran. Dorongan ini akan melahirkan timbulnya suatu perhatian terhadap suatu obyek (Priakusuma, Hasyim, \& Husin, 2013).

4) Perbaikan produk yang diuji coba

Produk yang sudah di uji cobakan pada kelompok kecil ini sudah bagus meski demikian perlu untuk diperbaiki oleh para ahli peresean dan guru penjas, dengan tujun agar produk tersebut lebih bagus tanpa ada keraguan responden untuk mengunakanya. Dorongan-dorongan yang ada pada diri anak, menggambarkan perlunya perlakuan yang luas, sehingga ciri-ciri dan minat anak tergambar lebih terinci dan faktual, sesuai dengan usia dan kedewasaan mereka.

\section{5) Uji Lapangan}

Uji lapangan atau uji kelompok besar sebagai ahir dari uji coba pada responden dan untuk mengetahui tingkat minat responden. Ditinjau dari uji kelompok besar minat responden sanagt tinggi artinya responden tidak segansegan saling pukul dan menangkis bahkan responden yang lain ingin mencoba dan 
mencoba. Berkaitan dengan hal itu diperjelas lagi melalui pertanyaan, dari pertanyaan tersebut diperoleh kerteria baik atau jawaban sebagian besar menjawab Ya dengan rata-rata persentsi 85\%. Jawaban tersebut diperkuat lagi dari pernyataan Ahli pembelajaran penjaskes menyatakan "Saya akan mendiskuusikan dengan bapak kepala sekolah dan waka kurikulum agar dimasukan diekstrakurekuler" (AR Penjas, 48 th). Permainan peresean dengan model pengembangan seperti ini merupakan model yang tepat untuk diberikan pada siswa tingkat SMA serta sebagai wujud pelestarian buaya sasak" (KP Ahli Peresean, 51 th). Dari hasil penelitian yang dilakukan oleh(Saryono, 2008), menyimpulkan bahwa permainan tradisional gobag sodor bola dapat digunakan guru penjas sebagai permainan alternatif dalam pembelajaran penjasorkes.

6) Revisi produk akhir yang dilakukan berdasarkan hasil uji lapangan.

Berdasarkan uji coba lapangan, para ahli tidak mengkomentari dari produknya dengan demikian tidak terdapat kekuranagan, hanya saja memberikan masukan saat sebelum main dan saat main peresean didampigi oleh guru penjas. Dengan masukan tersebut menjadi barometer agar dapat menilai peningkatanpeningkatan yang diperoleh siswa. Minat anak akan menjadi pedoman penyelenggaraan program pendidikan jasmani yang arahnya dapat dikategorikan dalam hasil belajar yaitu kognitif, afektif, psikomotor (Firdaus, 2012). Minat tersebut didukung dari luar atau faktor penguat sehingga memungkinkan akan terjadi perubahan sikap dan perilaku, konsekuensi dari determinan perilaku, dimana masyarakat menerima feedbackdan setelah itu ada dukungan sosial, meliputi pengaruh dan informasi serta umpan balik dari tenaga kesehatan, (Firdaus, 2012)

Penelitian yang sama juga yang diungkapkan dengan (Aminullah, Afrian, \& Suryansah, 2018) bahwa modifikasi peraturan permainan tradisional presean yang berdasarkan data pada saat uji coba produk memperoleh nilae rata-rata $63 \%$ dan uji coba sekala besar diperoleh nilai rata-rata $72 \%$, sehingga modifikasi peraturan permainan tradisional presean pada pembelajaran pendidikan jasmani olahraga dan kesehatan, dapat digunakan pada siswa Sekolah Dasar Islam NW Tanah Abror. Sedangkan (Hendra, Afrian, \& Suryansah, 2019) mengungkapkan 
modifikasi permainan olahraga tradisional presean ini memenuhi kriteria baik sehingga dapat digunakan untuk siswa Sekolah Dasar dengan hasil rata-rata $73 \%$. Pemebelajaran pendidikan jasmani olahraga dan kesehatan dibutuhkan pembelajaran yang variatif, inovatif, dan tidak membosankan maka dari itu memodifikasi olahraga maupun permainan akan lebih baik lagi dan akan lebih menarik agar siswa lebih aktif dalam proses pembelajaran.

\section{SIMPULAN}

Berdasarkan Hasil penelitian tentang model pengembangan permainan peresean dalam meningkatkan minat olahraga tradisional pada siswa kelas $\mathrm{X}$ di SMA Negeri 1 Praya Timur. Dari produk yang dikembangkan oleh peneliti dengan pengembangan model dari alat peresean, alat peresean ini kemudian diuji cobakan sehingga disenagi oleh responden. Responden memiliki ketertarikan yang antusias karena memang tidak membahayakan bagi pemain itu sendiri. Produk peresean yang dikembangkan dengan kesepakatan dari para ahli yaitu ahli peresean, guru penjas dan pepadu. Para ahli tersebut memberikan saran, masukan maupun teknis-teknis sehingga alat peraga peresean tidak berbahaya. Harapan peneliti ialah semoga olahraga tradisional peresean ini di masukan dalam kurikulum, sebagai wujud pelestarian budaya sasak atau lombok.

\section{DAFTAR RUJUKAN}

Aminullah, Afrian, H., \& Suryansah. (2018). Modifikasi Peraturan Permainan Tradisional Peresean Tingkat Sekolah Dasar Di SD Islam Nw Tanah Abror. Journal Porkes Hamzanwadi, $\quad$ 1(2), 46-49. https://doi.org/10.1017/CBO9781107415324.004

Djaali. (2011). Psikologi Pendidikan (5th ed.). Jakarta.

Firdaus, K. (2012). Psikologi Olahraga Teori dan Aplikasi. The British Journal of Psychiatry (Vol. 111). Padang: Fakultas Ilmu Keolahragaan Universitas Negeri Padang Press J1. Prof. Dr. Hamka, Kampus UNP Air Tawar Padang, 25131 CHak. https://doi.org/10.1192/bjp.111.479.1009-a

Firmansyah, G., \& Rahayu, E. D. (2019). Model Pembelajaran Gerak Dasar Melompat melalui Modifikasi Permainan Tradisional Engklek pada Anak Sekolah Dasar. Journal of Teaching Physical Education in Elementary 
School, 2(14), 111-117. https://doi.org/10.17509/tegar.v2i2.17822

Hendra, Afrian, H., \& Suryansah. (2019). Modifikasi Permainan Tradisional Peresean Tingkat Sekolah Dasar Di SD Islam NW Tanah Abror. Journal PORKES Hamzanwadi, 2(1), 21-24. https://doi.org/10.1017/CBO9781107415324.004

Husnan, M. A. (2009). 100 + Permainan Tradisional Indonesia Untuk Kreativitas, Ketangkasan, dan Keakraban (Andi).

Malik, A. A., Priyono, B., \& Qoriah, A. (2013). Media Permainan Edukatif Untuk Olahraga Dengan Menggunakan Sistem Sirkuit Training Bagi Siswa Kelas X SMA Negeri Ajibarang Tahun 2013. Active - Journal of Physical Education, Sport, Health and Recreation, 2(10), 630-636. https://doi.org/10.15294/active.v2i10.2018

Priakusuma, A., Hasyim, A., \& Husin, S. (2013). Penerapan Modifikasi Alat Pembelajaran Pendidikan Jasmani Untuk Peningkatan Hasil Belajar Atletik Nomor Lempar Cakram Pada Siswa Kelas VIII SMP Muhammadiyah 1 Pringsewu. Jurnal Teknologi Informasi Komunikasi Pendidikan, 1(1), 1-10. Rahayu, E. D., \& Firmansyah, G. (2019). Pengembangan Permainan Tradisional Lompat Tali Untuk Meningkatkan Kinestetic Intelegency Pada Anak Usia 11-12 Tahun. Jendela, 4(2), 8-12. https://doi.org/10.26877/jo.v4i2.3611

Rajab, B. A. S., \& Kuswantoro, R. B. H. (2018). Perancangan Game Fighting Peresean Sebagai Media Pengenalan Budaya Suku Sasak, XIII(November), $76-83$.

Riyanto, Y. (2007). Metodologi Penelitian Pendidikan Kualitatif dan Kuantitatif. Surabaya: Unesa University Press.

Rosianah, D., R, H. P., \& Setiawan, I. (2012). Model Pengembangan Permainan Gobag Sodor Bola Pada Pemb- Elajaran Bola Tangan Dalam Penjasorkes Siswa Kelas V Pada Sekolah Dasar. 4(7), 1957-1962.

Saryono. (2008). Jurnal Pendidikan Jasmani Indonesia. Jurnal Pendidikan Jasmani Indonesia, 4(1), 44-54.

Setyosari, \& Punaji. (2010). Metode Penelitian Pendidikan dan Pengembangan (4th ed.). Jakarta: PT Karisma Putra Utama.

Sriyatin, Sucipto, A., \& Sulikan. (2018). Peningkatan Hasil Belajar Pendidikan 
Jasmani Melalui Model Pembelajaran Kooperatif Tipe Jigsaw Siswa SDN Sambigede 03 Sumberpucung Malang. Jurnal Pendidikan, Jasmani, Olahraga Dan Kesehatan (Jp.jok), 1(2), 80-91.

Suharnoko, F., \& Firmansyah, G. (2018). Pengembangan Model Pembelajaran Melompat Melalui Permainan Lompat Cermin Untuk Siswa Sekolah Dasar. Jurnal SPORTIF : Jurnal Penelitian Pembelajaran, 4(2), 145-158.

Taufan, J., Ardisal, Damri, \& Arise. (2018). Pelaksanaan Pembelajaran Pendidikan Jasmani Adaptif Bagi Anak Dengan Hambatan Fisikdan Motorik. Jurnal Pendidikan Kebutuhan Khusus, 2(2), 1-6. 